\title{
Sudanese Oil Field Production Performance by Nodal Analysis Technique
}

\author{
Fatima A. Elbrir
}

\begin{abstract}
The study has evaluated production performance of oil well by using nodal analysis for entire production system. The goal of this study is to analysis one of the Sudanese oil field using nodal analysis and to review the field completion strategy for the respective field. The study starts by collecting the data from oil Company and takes the $\mathrm{X}$ Field as case study. The $X$ field consist of 18 well and four of them were selected for theanalysis namely X NW-1, X NW-2, X NW-3 and X NW-4. Operating pressure for each well are 2409, 2455,2550 and 2420 psia, and operating flow rate are 3925.4, $1110.4,2255.7$, and 1387.2 STB/D respectively. Wellfl modeling used for this task, which permits the production optimization of oil well using the concept of nodal analysis.

Several sensitivity analyses were conducted in order to get the production forecast. If assumed thatthe depletion in the pressure occur within 1 year, the pressure reduced to 2000 and 1000psia for each well; as can be seen, the production reduced rapidly inXNW-2 and XNW-4. However, 1000psia the production becomes zero for the four wells.
\end{abstract}

Index Terms - Nodal Analysis, Production Performance, Wellflo Progam.

\section{INTRODUCTION}

Nodal analysis has long been a key method used to evaluate the performance of an integrated production system [1]. It has performed in the sixties and seventies by hand calculation, using vertical pressure traverse graphs generated in- house by big oil companies [2], and define the propositions that will be used to optimize a production system, for oil and gas well. Each component of the producing system is analyzed in order to reach the desired production rate as economical as possible [3].

- Determine the fluid rate that an oil or gas well will produce, taking into account the hole geometry and the completion boundaries.

- Optimize the system to produce an objective fluid rate as economical as possible [4]. Nodal analysis provides a method to determine the flow rate at which a producing system will perform under applied condition.

The node is placed into different location. The node is classified as a functional node when a pressure exists across it and the pressure or flow rate response can be presented by some mathematical or physical function [3]. Once the node is selected, the node pressure is calculated from the both directions stared at the fixed pressures. In other words, the flow into the node equals the flow out the nod [5].

Published on January 18, 2020.

Fatima A. Elbrir, Sudan University of Science and Technology, Sudan. (e-mail: fatimawael12@hotmail.com)

\section{APPLICATION OF FIELD X NODAL ANALYSIS}

\section{A. Models and Correlations}

The Wellflo computer program software was used for nodal analysis. For this study version (3.8) has been used. The computer program can conduct the nodal analysis calculations as well as (sensitivity analysis) and tested with actual field data.

Reservoir: The pressure drops across the reservoir porous media are computed by an inflow performance relationship (IPR) expressed by Vogel's [6].

$$
\frac{q_{o}}{q_{0(\max )}}=1-0.2 \frac{p_{w f}}{\overline{p_{R}}}-0.8\left(\frac{p_{w f}}{\overline{p_{R}}}\right)^{2}
$$

Perforation: The program computes the pressure drop across the perforations using Mc-Leod's method [7]. The equation for the pressure losses across the perforation is as follows:

$$
p_{w f s-} p_{w f}=a q+b q^{2}
$$

The coefficient $\mathrm{a}$ and $\mathrm{b}$ are define $\mathrm{as}$,

$$
\begin{aligned}
& a=\frac{3.16 * 10^{-12} * \beta * \gamma * T *\left(\frac{1}{R p}-\frac{1}{R c}\right)}{L P^{2} * \mu} \\
& b=\frac{1.424 * 10^{3} * T *\left(\operatorname{Ln} \frac{R c}{R p}\right)}{K_{P} * L_{P}}
\end{aligned}
$$

Tubing String: Hagedron and Brown correlation was used to compute the pressure drop across the tubing string.

Well Head Choke: Sechdeva, Adiatique expansion equation and Gilbert correlations used to compute the pressure losses across the wellhead choke [8].

Surface Pipeline: Hagedron and Brown correlation were used to compute the pressure drop across the surface pipeline, this equation considers slip condition and flow regime, used for all pipe size, and for the all fluids.

Fluid Properties: The correlations used to build the wellflo software program to estimate the properties of the fluids are listed in Table (1). These experimental correlations are function of temperature, pressure, type of fluid (gas, oil or water), and densities of the different phase which are present in the flow. 
TABLE 1: CORRELATION FOR FLUID PROPERTIES

\begin{tabular}{ccc}
\hline Fluid property & Correlation & Utilized \\
\hline $\begin{array}{c}\text { Solution Gas-Oil } \\
\text { ratio }\end{array}$ & Glaso & \multirow{2}{*}{ Glaso } \\
\cline { 2 - 2 } $\begin{array}{c}\text { Formation volume } \\
\text { factor } \\
\text { Bubble point } \\
\text { pressure }\end{array}$ & Laster & \\
\cline { 2 - 3 } & Standing & \\
\hline Surface tension & Aazquez- Beggs & Advanced \\
\hline Oil viscosity & Macary & Beal+chew et \\
& Beggs et al \&Astm+chequet al & al Basic \\
\hline
\end{tabular}

\section{B. Field X Data validation and Results}

4 wells namely XNW1, XNW2, XNW3, and XNW4 were selected, all of the four well open to production in 2009. X field data represent an ideal production data which is used to verify the robustness of wellflo software program. The characteristics of the reservoir as well as the completion, production, and fluid properties, for four well are summarized in following Tables 2-6.

TABLE 2: X FIELD RESERVOIR DATA

\begin{tabular}{ccccc}
\hline Well name & XNW-1 & XNW-2 & XNW-3 & XNW-4 \\
\hline Initial pressure (psi) & 2409 & 2455 & 2550 & 2420 \\
\hline Initial temperature (f) & 186 & 179 & 180 & 179 \\
\hline Net pay (ft) & 84.6 & 38 & 50.5 & 49.5 \\
\hline Porosity (fraction) & 0.21 & 0.19 & 0.24 & 0.22 \\
\hline Permeability (md) & 2400 & 212 & 2000 & 1800 \\
\hline $\begin{array}{c}\text { Water saturation } \\
\text { fraction) }\end{array}$ & 0.48 & 0.44 & 0.25 & 0.29 \\
\hline
\end{tabular}

TABLE 3: X FIELD COMPLETION DATA

\begin{tabular}{ccccc}
\multicolumn{5}{c}{ TABLE 3: X FIELD COMPLETION DATA } \\
\hline Well name & XNW-1 & XNW-2 & XNW-3 & XNW-4 \\
\hline Casing diameter [in.] & \multicolumn{5}{c}{6.267} \\
\hline Perforated interval [ft] & 131.2 & 55.8 & 62 & 57.4 \\
\hline Perforation density [SPF] & \multicolumn{5}{c}{4} \\
\hline
\end{tabular}

TABLE 4: X FIELD PRODUCTION DATA

\begin{tabular}{ccccc}
\hline Well name & XNW-1 & XNW-2 & XNW-3 & XNW-4 \\
\hline Well head pressure $[\mathrm{psia}]$ & 390 & 265 & 235 & 280 \\
\hline Well head temperature $[\mathrm{F}]$ & 164 & 150 & 155 & 143 \\
\hline Gas oil ratio (SCF/STB) & 30 & 30 & 30 & 30 \\
\hline Water cut \% & 50 & 80 & 92 & 9 \\
\hline $\begin{array}{c}\text { Liquid production rate } \\
\text { (STB/d) }\end{array}$ & 3925.4 & 1110.4 & 2255.4 & 1387.2 \\
\hline
\end{tabular}

TABLE 5: X FIELD FLUID PROPERTIES DATA

\begin{tabular}{|c|c|c|c|c|}
\hline Well name & XNW-1 & XNW-2 & XNW-3 & XNW-4 \\
\hline $\begin{array}{l}\text { Specific gravity of } \\
\text { produced gas }\end{array}$ & \multicolumn{4}{|c|}{0.65} \\
\hline Oil density [API] & 37.05 & 35.11 & 39.1 & 36.06 \\
\hline $\begin{array}{c}\text { Solution gas/oil ratio } \\
\text { correlation: }\end{array}$ & \multicolumn{4}{|c|}{ Glaso } \\
\hline $\begin{array}{l}\text { Oil formation volume factor } \\
\text { correlation: }\end{array}$ & \multicolumn{4}{|c|}{ Glaso } \\
\hline $\begin{array}{c}\text { Bubble point pressure } \\
\text { correlation: }\end{array}$ & \multicolumn{4}{|c|}{ Glaso } \\
\hline Oil viscosity correlation: & \multicolumn{4}{|c|}{ Beal + chew et al } \\
\hline Gas viscosity correlation: & \multicolumn{4}{|c|}{ Carr et al } \\
\hline Surface tension & \multicolumn{4}{|c|}{ Advanced } \\
\hline Water salinity (ppm) & \multicolumn{4}{|c|}{5878} \\
\hline
\end{tabular}




\begin{tabular}{|c|c|c|c|c|c|c|c|c|c|c|c|}
\hline \multicolumn{3}{|c|}{ Xnw-1 } & \multicolumn{3}{|c|}{ Xnw-2 } & \multicolumn{3}{|c|}{ Xnw-3 } & \multicolumn{3}{|c|}{ Xnw-4 } \\
\hline $\begin{array}{c}\text { Layer } \\
\text { Pressure } \\
\text { Psia } \\
\end{array}$ & $\begin{array}{l}\text { Gross } \\
\text { STB/d }\end{array}$ & $\begin{array}{l}\text { Oil } \\
\text { STB/d }\end{array}$ & $\begin{array}{c}\text { Layer } \\
\text { Pressure } \\
\text { Psia } \\
\end{array}$ & $\begin{array}{l}\text { Gross } \\
\text { STB/d }\end{array}$ & $\begin{array}{c}\text { Oil } \\
\text { STB/d }\end{array}$ & $\begin{array}{c}\text { Layer } \\
\text { Pressure psia }\end{array}$ & $\begin{array}{l}\text { Gross } \\
\text { STB/d }\end{array}$ & $\begin{array}{c}\text { Oil } \\
\text { STB/d }\end{array}$ & $\begin{array}{c}\text { Layer } \\
\text { Pressure } \\
\text { Psia } \\
\end{array}$ & $\begin{array}{l}\text { Gross } \\
\text { STB/d }\end{array}$ & $\begin{array}{c}\text { Oil } \\
\text { STB/d }\end{array}$ \\
\hline 2400 & 3964 & 1982 & 2455 & 1141 & 228 & 2455 & 2107.4 & 163 & 2420 & 1335.8 & 996 \\
\hline 2000 & 3190 & 1595 & 2400 & 789.7 & 157 & 2400 & 1939 & 155 & 2400 & 1094.8 & 927 \\
\hline 1000 & \multicolumn{2}{|c|}{$\begin{array}{l}\text { No operating } \\
\text { Point }\end{array}$} & 2000 & \multicolumn{2}{|c|}{$\begin{array}{l}\text { No operating } \\
\text { Point }\end{array}$} & 1500 & No o & ating & 1500 & \multicolumn{2}{|c|}{$\begin{array}{c}\text { No operating } \\
\text { Point }\end{array}$} \\
\hline
\end{tabular}

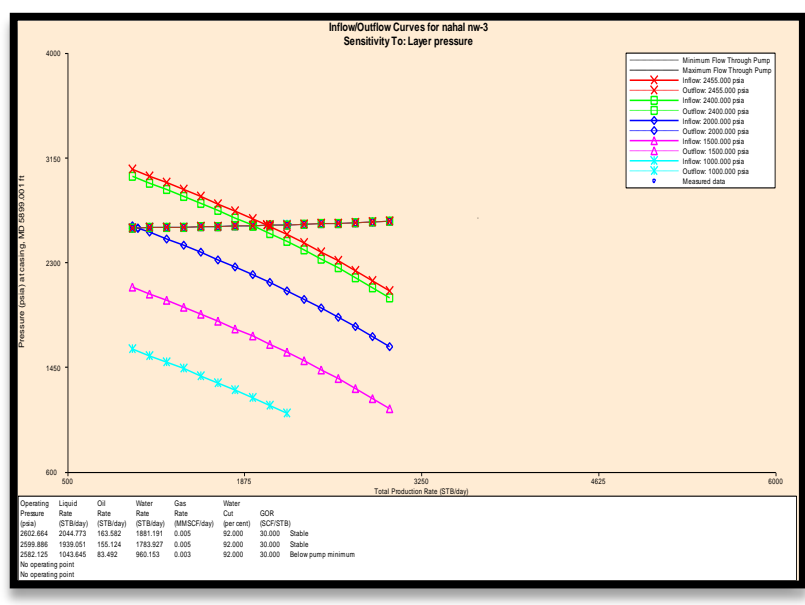

Fig. 2. Sensitivity of Flow Rate with Respect to Layer Pressure for (xnw3).
Well Head Pressure: The sensitivity of the four well shown in Table 8, the actual wellhead pressures of the four well are $(380,265,235$ and 280 psia) respectively, different values of pressure were taken for the forecasting the four wells. The results show that the well performance improves as the well head pressure decreases. The decrease of wellhead pressure from 380 psia to 350 psia provided an increase in flow rate of about $288 \mathrm{~b} / \mathrm{d}$ for the well xnw-1. However, a further decrease of well head pressure from 200 psia to 150 psia provided an increase of about $118 \mathrm{~b} / \mathrm{d}$. Moreover, the gain resulting from an eventual decrease of the well head pressure from 150 to100 psia provided an increase in flow rate of about $101 \mathrm{~b} / \mathrm{d}$. the decrease of well head pressure resulting in increasing the flow rate about 185 b/d for well xnw-3 and 174b/d flow rate was achieved for the well xnw-4.

\begin{tabular}{|c|c|c|c|c|c|c|c|}
\hline \multicolumn{2}{|c|}{ Xnw-1 } & \multicolumn{2}{|c|}{ Xnw-2 } & \multicolumn{2}{|c|}{ Xnw-3 } & \multicolumn{2}{|c|}{ Xnw-4 } \\
\hline $\begin{array}{c}\text { Pressure } \\
\text { Psia }\end{array}$ & $\begin{array}{c}\text { Rate } \\
\text { STB/d }\end{array}$ & $\begin{array}{c}\text { Pressure } \\
\text { Psia }\end{array}$ & $\begin{array}{c}\text { Rate } \\
\text { STB/d }\end{array}$ & $\begin{array}{c}\text { Pressure } \\
\text { Psia }\end{array}$ & $\begin{array}{c}\text { Rate } \\
\text { STB/d }\end{array}$ & $\begin{array}{c}\text { Pressure } \\
\text { Psia }\end{array}$ & $\begin{array}{c}\text { Rate } \\
\text { STB/d }\end{array}$ \\
\hline 380 & 3723 & 265 & 1141 & 235 & 2107 & 280 & 1335 \\
\hline 350 & 4011 & 200 & 1365 & 200 & 2292 & 200 & 1509 \\
\hline 300 & 4089 & 150 & 1484 & 150 & 2379 & 150 & 1596 \\
\hline - & - & 100 & 1585 & 100 & 2467 & 100 & 1678 \\
\hline
\end{tabular}

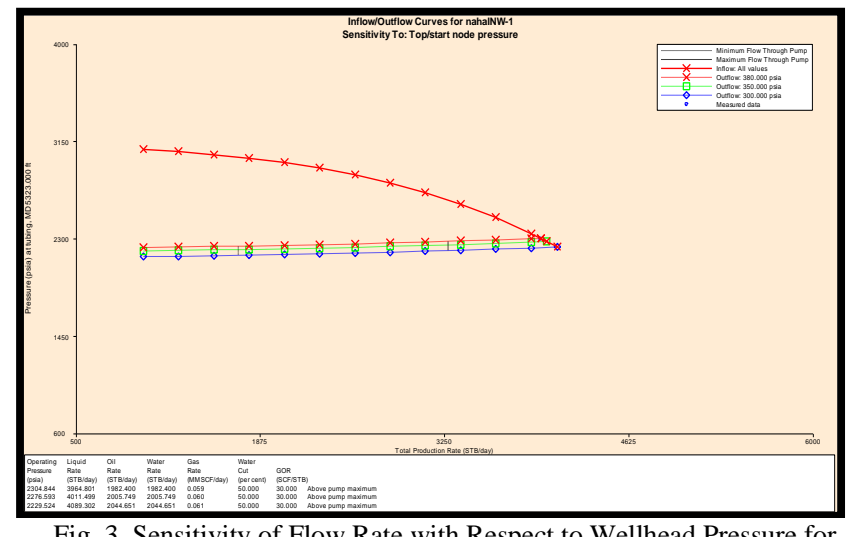

Fig. 3. Sensitivity of Flow Rate with Respect to Wellhead Pressure for (xnw-1).

Water Cut: In order to evaluate the viability of producing the four wells under increased water-cuts and reduced reservoir pressures, a number of sensitivity analyses were performed on the production from the four wells using WellFlo. The results summarized in Table 9. The actual water cut of the well $\mathrm{xnw}-1$ is $50 \%$. Therefore, a water cut values of $50 \%, 70 \%$, and $90 \%$ are used for forecast computations for this well. The results show that when the water cut becomes $90 \%$, the oil produced is $379 \mathrm{stb} / \mathrm{b}$ but it

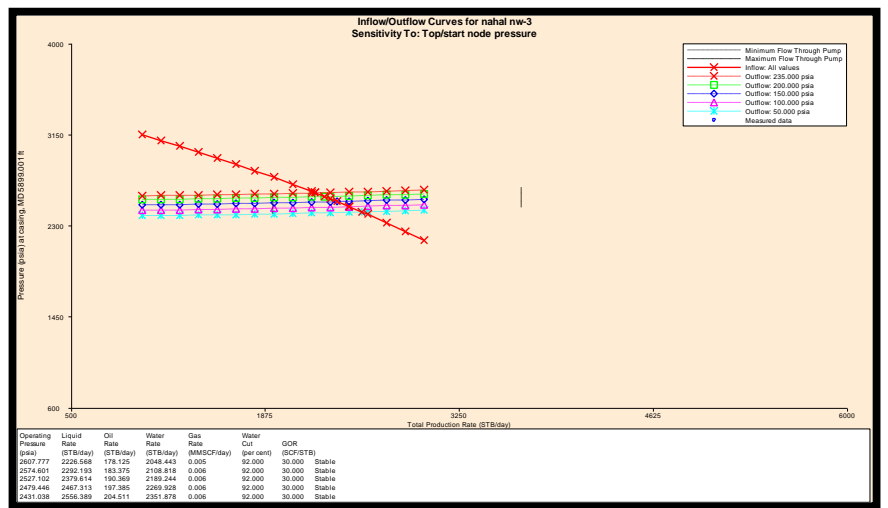

Fig. 4. Sensitivity of Flow Rate with Respect to Wellhead Pressure for (xnw-3).

is reasonable comparing with other wells. Water cut value of $80 \%, 85 \%$ and $90 \%$ were used for forecast computation for well xnw-2 since the actual water cut of this well is $80 \%$. Simulation shows, this well produced only $41 \mathrm{stb} / \mathrm{d}$ when the water cut increasing to $90 \%$. The same procedure was conducted for the other wells and the results shown in the following. 
TABLE 9: SENSITIVITY OF WATER CUT

\begin{tabular}{|c|c|c|c|c|c|c|c|c|c|c|c|}
\hline \multicolumn{3}{|c|}{ Xnw-1 } & \multicolumn{3}{|c|}{ X nw-2 } & \multicolumn{3}{|c|}{ X nw-3 } & \multicolumn{3}{|c|}{ X nw-4 } \\
\hline WC\% & $\begin{array}{l}\text { Goss } \\
\text { Stb/d }\end{array}$ & $\begin{array}{c}\text { Oil } \\
\text { Stb/d }\end{array}$ & WC\% & $\begin{array}{l}\text { Gross } \\
\text { Stb/d }\end{array}$ & $\begin{array}{c}\text { Oil } \\
\text { stb/d }\end{array}$ & $\mathrm{WC} \%$ & $\begin{array}{l}\text { Gross } \\
\text { Stb/d }\end{array}$ & $\begin{array}{c}\text { oil } \\
\text { stb/d } \\
\end{array}$ & $\mathrm{WC} \%$ & $\begin{array}{l}\text { Gross } \\
\text { Stb/d }\end{array}$ & $\begin{array}{c}\text { Oil } \\
\text { stb/d }\end{array}$ \\
\hline 50 & 3723 & 1982 & 80 & 1141.7 & 228 & 92 & 2226.6 & 178 & 20 & 1276.7 & 1014 \\
\hline 70 & 3881.6 & 1164 & 85 & 1060.8 & 159 & 95 & 2248 & 112 & 50 & 991.6 & 495.8 \\
\hline 90 & 3790.5 & 379 & 90 & 961 & 41.5 & 98 & 2270.8 & 45 & 80 & No oper & point \\
\hline
\end{tabular}

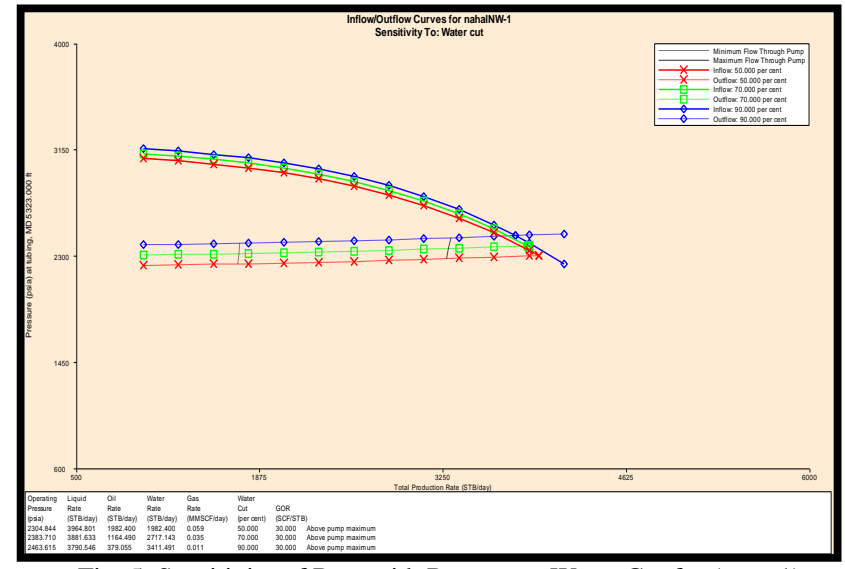

Fig. 5. Sensitivity of Rate with Respect to Water Cut for (xnw-1).

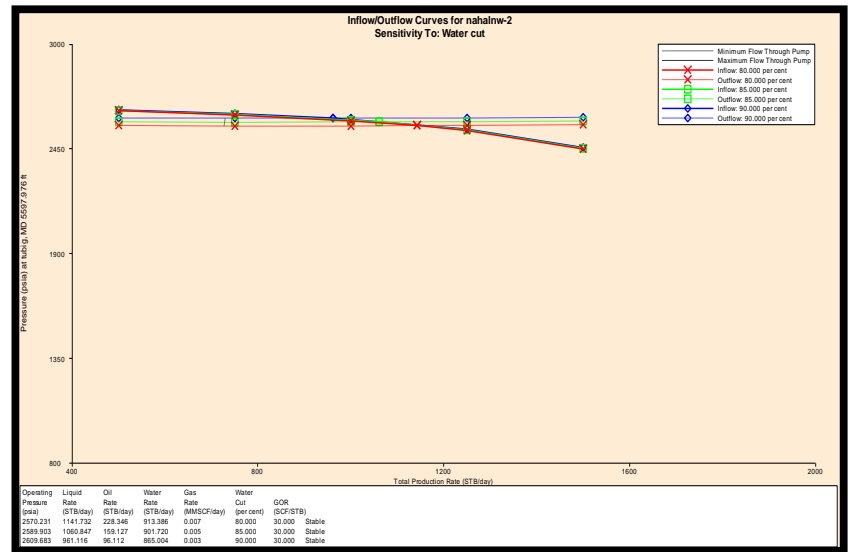

Fig. 6. Sensitivity of Rate with Respect to Water Cut for (xnw-2).

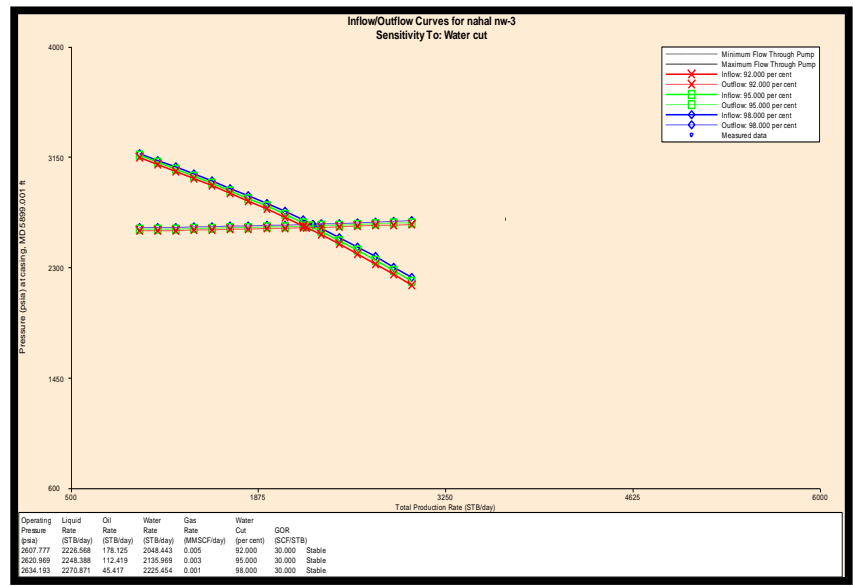

Fig. 7. Sensitivity of Rate with Respect to Water Cut for (xnw-3).

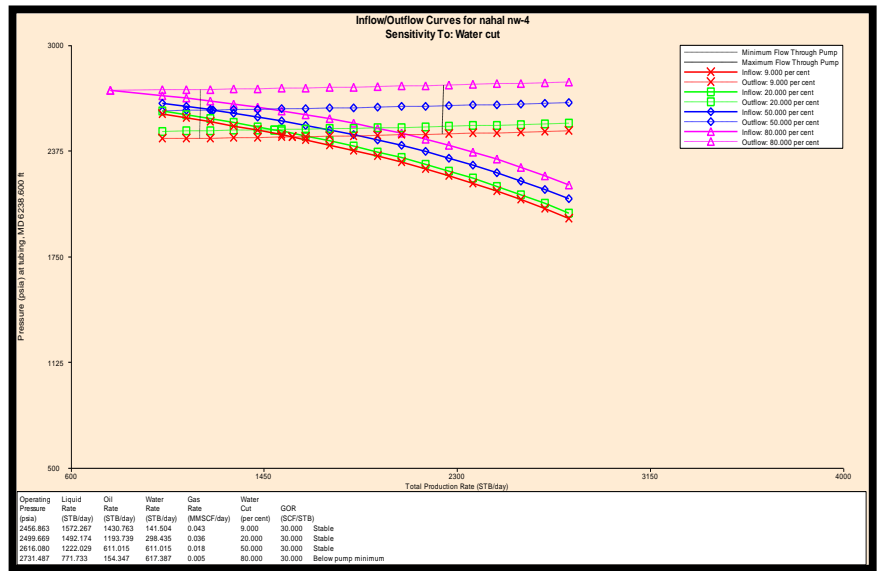

Fig 8. Sensitivity of Rate with Respect to Water Cut for (xnw-4).

\section{CONCLUSION}

Several innovative ideas during the courses of data collection, implementation in wellflo program, history matching, and sensitivity analysis are presented the finding prove that the nodal analysis provides valuable means to help the engineer in Decisions making. Opening oil well to production always involves considerable expenses whereas a model can be run many times at lower cost to try many different possible scenarios in order to make technical and economic decisions. The wellflo program presented in this study is capable of history matching the production data as well as predicting the performance under different scenarios. The program has been validated with the help of field data. The program definitely provides a logical improvement in nodal analysis.

\section{FURTHER WORK}

For future researches is better to include the difference between the inflow and out flow due to friction through the production pipes which was not considered in this study, also there are so many factors can be considered in the coming researches such as GOR, inside diameter of all well node, Roughness of all well node, effective permeability, layer thickness, wellbore radius, external radius and total Darcy skin.

\section{NOMENCLATURE}

$P_{r}-$ The reservoir pressure, psia

$P_{\text {sep }}$ - The separator pressure, psia

$q_{o}$ - Inflow rate corresponding to wellbore flowing pressure, STB

$q_{o} \max$ - Inflow rate corresponding to zero wellbore flowing pressure, STB/d

$\overline{P_{R}}$ - Average reservoir pressure, psia 
$R_{P}-$ Radius of perforation, $\mathrm{ft}$

$R_{C}$ - Radius of compacted zone, $\mathrm{ft}$

$\mu-$ Viscosity, cp

$\gamma$-Specific gravity, dimensionless

$K_{P}$ - Permeability of compacted zone, md

$L_{P}-$ Perforation tunnel length, $\mathrm{ft}$

$T$ - Temperature, $\mathrm{R}$

$P_{w f}-$ Bottom hole flowing pressure

$P_{w f s}$ - Sand face flowing pressure

$A_{R}$ - Laminar reservoir component

$K_{O R}$ - Unaltered reservoir permeability to oil

$S_{d}$ - Skin factor due to permeability alteration around the wellbore

$K_{R}-$ Reservoir permeability

$K_{d}$ - Alternated zone permeability

$r_{w}-$ Wellbore radius

$r_{d}$ - Alternated zone radius

$B_{R}$ - Turbulent reservoir component

$A_{G}$ - Laminar gravel-pack component

$B_{G}$ - Turbulent gravel-pack component

$N$ - Total number of perforation

$L$ - Gravel-pack tunnel length

$K_{G^{-}}$- Gravel-pack permeability

$P_{w h}-$ Wellhead pressure, psia

$R-$ Gas/liquid ratio, MCF/STB

$Q-$ Gross liquid rate, STB/D

$S$ - Choke bean size, $64^{\text {th }}$ of an inch

$C$ - Constant

\section{REFERENCES}

[1] Beggs, H. (2003). 'Production optimization: using NODAL analysis'. 2nd Edition. (Tulsa, Okla.: OGCI and Petroskills Publications: Tulsa).

[2] Arslan, O., Wojtanowicz, A.K., and, White, C.D., (2004) "Nodal Analysis for Oil Well with down hole Water sink Completions". SPE The paper was presented at the petroleum society 5 th.

[3] Awal, R. M; (2009). "Anew Nodal Analysis Technique Helps Improve Well Completion and Economic Performance of Matured Oil Fields," SPE 120632 university of Texas Tech.

[4] North, R., and, Lenn, C.P., "Managing Production in Maturing Assets: Increasing intervention Success by Combining Production Logging with Nodal Analysis". SPE 104629 The paper was presented at the SPE Middle East oil \& gas (2007).

[5] Begges, D.H.; 1999. "Production Optimization Using Nodal Analysis," OGCI, Tulsa, Oklahoma.

[6] Ozdogan, U., Keating, J. F., Knobles, M. M., Chawathe, A., and Seren, D. (2008). Recent Advances and Practical Applications of Integrated Production Modeling. SPE Europec/EAGE Annual Conference and Exhibition, 9-12 June, Rome, Italy. (Society of Petroleum Engineers). 10.2118/113904-MS.

[7] Lorezo, A.C., "Anew Alternative in the Performance Monitoring and control of the Reservoir- Artificial Lift System for the Optimization of the producing Well", SPE 69463. Latin American and Caribbean Petroleum Engineering Conference held in Buenos Aires, Argentina, (25-28 March 2001).

[8] Perez, G. and Kelkar, B.G.; "A simplified Method to Predict Over-all Production Performance," Journal of Canadian Petroleum Technology, (January-February, 1990), Volume29, No.1. 